\title{
Comparative Evaluation of Acute Toxicity of Butaforce and Termex Pesticides on Bufo regularis Tadpole
}

\author{
Constance Obiageli Ejilibe ${ }^{1}$, Helen Ogochukwu Nwamba ${ }^{2}$, Chiamaka Lynda Ani ${ }^{2}$, Chinedu Ifeanyi Atama ${ }^{3}$ and \\ Christopher Didigwu Nwani ${ }^{3 *}$ \\ ${ }^{1}$ Department of Biology, Federal college of Education, Nigeria \\ ${ }^{2}$ Department of Applied Biology and Biotechnology, Enugu State University of Science and Technology, Nigeria \\ ${ }^{3}$ Department of Zoology and Environmental Biology, University of Nigeria Nsukka, Nigeria \\ *Corresponding author: Christopher Didigwu Nwani, Department of Zoology and Environmental Biology, University of Nigeria Nsukka, Nigeria \\ Submission: 侮 January 16, 2018; Published: 望 February 26, 2018
}

\begin{abstract}
Water contamination is a current environmental problem in different parts of the world and a huge variety of pesticides are involved in this process. Butaforce is a major herbicide used in agriculture for the control of grass and other broad leaves while termex is an insecticide used for the control of termites and other insects in homes and agricultural fields. The present study evaluated the toxicity of these two widely used agricultural pesticides, butaforce and termex on Bufo regularis tadpole. The $96 \mathrm{~h} \mathrm{LC}_{50}$ of butaforce and termex on B. regularis were $0.42 \mathrm{mg} / \mathrm{L}$ and $1.13 \mathrm{mg} / \mathrm{L}$ respectively. The safe levels ranged from $4.20 \times 10^{-2} \mathrm{mg} / \mathrm{L}$ to $4.20 \times 10 \mathrm{mg} / \mathrm{L}$ in butaforce and from $1.13 \times 10^{-1}$ to $1.13 \times 10^{-5}$ in termex. The results also indicate concentration and duration dependent increase in mortality rates of $C$. gariepinus exposed to the pesticides. There were significant differences ( $<<0.05)$ in LC(1090), no observe effect concentration (NOEC) and lowest observed effect concentration (LOEC) for different times of exposures. While the maximum allowable concentration (MAC) of butaforce was $4.2 \mathrm{mg} / \mathrm{L}$ in B. regularis tadpole the value increased to $11.30 \mathrm{mg} / \mathrm{L}$ in termex showing that butaforce was more toxic to $B$. regularis than termex. The preset findings suggest that both pesticides were toxic to $B$. regularis and should be used with utmost care in our environment.
\end{abstract}

Keywords: Pesticides; Lethal concentrations; Amphibians; Nigeria

\section{Introduction}

The introduction of pesticides in pest management by agriculturalists is very vital for increase food production. However, this benefit is not without negative impact on the ecological system especially aquatic habitat as studies have shown that $99 \%$ of applied pesticides go into the air, water and soil and only $1 \%$ reach the target organism [1]. Butaforce and termex are widely used pesticides in Nigeria and other developing countries for the control of weeds and termites respectively. Butaforce (2-chloro-N-2, 6-diethylphenyl acetamide) is commercial herbicide formulations used for the control of grasses in rice fields and many broad leaf weeds whereas termex is a trade name for termiticide emulsiphable concentrate formulation of imidacloprid used for pre and post protection of building against termite. The Amphibian eggs and tadpoles can be exposed to pesticides while feeding in contaminated water or sediments [2]. Studies have shown decline in amphibian population due to pollution, disease outbreak and climate change [3] Pesticides from agricultural run-offs impair the normal balance of the flora and fauna of the aquatic ecosystem [4].
When run-off containing pesticides enter the aquatic ecosystem, the concentrations are rapidly diluted and are partitioned among various components of hydrosphere [5].

Bufo regularis tadpoles play an important role in aquatic ecosystem. They act both as consumers and prey to other species thus, contribute to energy transfer in the energy budget. Tadpoles are mostly herbivores feeding on algae, detritus and some plants, although they also eat other animals in small amount [6]. However the loss of tadpoles could affect the ecosystem of freshwater streams as tadpoles play a significant role in maintaining the structure and function of streams [7]. The presence of pesticides in surface water systems is a concern because of their potential adverse effect on human and animal health, and aquatic ecosystems. Tadpoles are more susceptible to pollution than birds or mammals because of permeable skin. Therefore, if aquatic environment is altered continuously by chemical contaminants it creates danger to aquatic biotaleading to decline in Bufo regularis population. Despite the huge use of agricultural pesticides in Nigeria, no published information 
has been reported to the best our knowledge, on the toxicity of butaforce and termex on Bufo regularis tadpoles. There is thus, the need to investigate the effects of butaforce and termex pesticides on aquatic organisms such as Bufo regularis tadpoles. The tadpoles are wide spread in most wet agricultural fields, can acclimatize easily under laboratory conditions and can thus be used as good sentinel organism for toxicological studies. The present study was desinged to determine the cumulative mortality, median lethal concentration $\left(\mathrm{LC}_{50}\right)$, safe level, no observe effect concentration (NOEC), lowest observed effect concentration (LOEC) and the maximum allowable concentration (MAC) of butaforce and termex pesticides on Bufo regularis tadpoles.

\section{Materials and Methods}

\section{Experimental animal and chemical}

A total of three hundred (300) freshwater Bufo regularis tadpoles (Family: Bufonidae; Order: Anura) were collected from the stagnant pool in the Biological Garden, Department of Biology, Federal College of Education Eha-Amufu Enugu state, Nigeria using hand net. The tadpoles were transported in Four 100L plastic aquaria containing the habitat water collected from the same pool to the Fisheries Wet Laboratory, University of Nigeria Nsukka, Nigeria. They were acclimatized for ten days in the same plastic aquaria prior to the experiment. Water was changed daily and the aquaria cleaned thoroughly to remove faecal matter and other waste materials. The tadpoles were fed with algae three times daily. Any dead tadpoles were removed instantly with forceps to maintain good quality of the test water. The feeding of the experimental organism was stopped $24 \mathrm{~h}$ before the commencement of lethal toxicity test to prevent fouling of the test water [8,9]. The institutional ethical Committee on Experimental Animal Care (UNN-EGACC-01618) was obtained and followed carefully. The herbicide (butarforce) and termiticide (termex) were purchased from agrochemical shop in the local market. The butachlor (trade name butaforce, China Agro Crop Care Co. Ltd China, containing 50\% butachlor as an active ingredient) and termex (trade name termex, Rallis India Limited Mumbai, containing imidacloprid 30.5\% SC) were used as the stock solutions.

\section{Acute toxicity test}

The acute toxicity of pesticides to aquatic organisms like toad, frog and fish are evaluated by the measurement of $\mathrm{LC}_{50}$ value that is, concentration of pesticide that results in $50 \%$ mortality of the test organism during exposure period (12 - 96 hours). Five concentrations of butaforce $(0.35,0.45,0.55,0.65,0.75 \mathrm{mg} / \mathrm{L})$ and five termex concentrations $(0.72,0.96,1.2,1.44,1.68 \mathrm{mg} / \mathrm{L})$ along with their controls were selected for exposures after a series of range finding tests. A set of 10 Bufo regularis tadpoles were randomly exposed to each of the selected concentrations in 40 - $\mathrm{L}$ glass aquaria $(60 \times 30 \times 30 \mathrm{~cm}$ size $)$ and were set in triplicates Another set of 10 tadpoles was set up as control in triplicates under the same laboratory condition but contained only tap water in place of any pesticide. The experimental set up were renewed every alternate days to maintain the concentration of the chemicals.
The temperature, $\mathrm{pH}$, dissolved oxygen, conductivity and water hardness of the test water were determined according to [10] method. The mortality and survival values were recorded from 24 to $96 \mathrm{~h}$ exposure duration. Any dead fish was sorted and removed from the tank to prevent fouling of the set up. The median lethal concentration $\left(\mathrm{LC}_{50}\right)$ which is the concentration at which $50 \%$ mortality occurred was determined by probit analysis using SPSSversion 17. The NOEC, LOEC and MAC were determined for each pesticide at the end of acute toxicity test [11]. The safe levels of the two pesticides were estimated by multiplying the $96 \mathrm{~h}$ LC50 with different application factors (AF) according to [12-17 ].

\section{Statistical analysis}

The data obtained were analyzed using the statistical package SPSS 17 computer program (SPSS Inc. Chicago, IL, USA) The data was subjected to one-way analysis of variance while Duncan's multiple range tests were used to determine significance difference at $5 \%$ probability. Results were expressed as means \pm standard error

\section{Results and Discussion}

The physico-chemical parameters of the test water indicate that the water temperature varied from $24.40{ }^{\circ} \mathrm{C}$ to $26.40{ }^{\circ} \mathrm{C}$ while the $\mathrm{pH}$ ranged from 7.2 to 7.6 . The dissolved oxygen varied from 6.4 to $7.2 \mathrm{mg} / \mathrm{L}$, conductivity from 250 to $280 \mu \mathrm{M} / \mathrm{cm}$ and the water hardness from 180 to $240 \mathrm{mg} / \mathrm{L}$. The results of acute toxicity study indicate concentration and duration dependent mortality of Bufo regularis tadpoles exposed to butaforce and termex pesticides respectively. After $96 \mathrm{~h}$ exposure to 0.35 and $0.75 \mathrm{mg} / \mathrm{L}$ concentrations of butaforce, $33 \%$ and $100 \%$ mortality of Bufo regularis tadpoles were recorded while $14 \%$ and $100 \%$ mortality were observed in tadpoles exposed to 0.7 and $1.68 \mathrm{mg} / \mathrm{L}$ concentrations of Termex (Table 1). The control group recorded $100 \%$ survival for both experiments. The results indicate that butaforce (herbicide) was more toxic compared to termex (insecticide). Similar results, have been reported in tadpoles and larvae of amphibian species exposed to related pesticides [3,4,6,1821]. The response curve of Bufo regularis tadpole after $96 \mathrm{~h}$ acute exposure to butaforce and termex (Figures $1 \& 2$ ) generally indicate that mortality of the tadpole is dependent on concentrations of the pesticides.The safe levels of the pesticides were determined by multiplying the $96 \mathrm{~h} \mathrm{LC}_{50}$ with different application factors (AF) varied from $4.20 \times 10^{-2} \mathrm{mg} / \mathrm{L}$ to $4.20 \times 10^{6} \mathrm{mg} / \mathrm{L}$ in butaforce and from $1.13 \times 10^{-1}$ to $1.13 \times 10^{-5} \mathrm{mg} / \mathrm{L}$ in termex (Table 2). The safe levels recorded for the two pesticides indicated some variations but in view of the controversy arising from the extrapolation of laboratory data to field it has been difficult in accepting safe levels based on laboratory experiment $[22,23]$. In line with our study [20] recorded safe levels of $0.073 \mathrm{mg} / \mathrm{L}$ and $0.044 \mathrm{mg} / \mathrm{L}$ for endosulfan and diazinon respectively on adult Amphibians (Bufo regularis). The $96 \mathrm{~h} \mathrm{LC}_{50}$ of $0.42 \mathrm{mg} / \mathrm{L}$ and $1.13 \mathrm{mg} / \mathrm{L}$, obtained for butaforce and termex respectively showed that both pesticides were toxic to Bufo regularis tadpoles. Similar to our results, [20] obtained $\mathrm{LC}_{50}$ of 0.73 and $0.44 \mathrm{mg} / \mathrm{L}$ in adult Bufo regularis exposed 
to endosulfan and diazinon respectively. While [6] obtained $\mathrm{LC}_{50}$ of $0.074 \mathrm{mg} / \mathrm{L}$ for Rana Dalmatina tadpoles exposed to endosulfan, [21] obtained $\mathrm{LC}_{50}$ of $5.38 \mathrm{mg} / \mathrm{L}$ for Physalaemus albonotatus exposed to glyphosate. [24] also obtained $\mathrm{LC}_{50}$ value of $20.81 \mathrm{mg} / \mathrm{L}$ in Osteopilus septentrionalis (Family Hylidae) exposed to glifosan pesticide. The variations in the $\mathrm{LC}_{50}$ in the different pesticides and groups of amphibians may depend on the types of pesticides, the speies of organisms, life stages, time, duration of exposure and the prevailing environmental conditions [25].

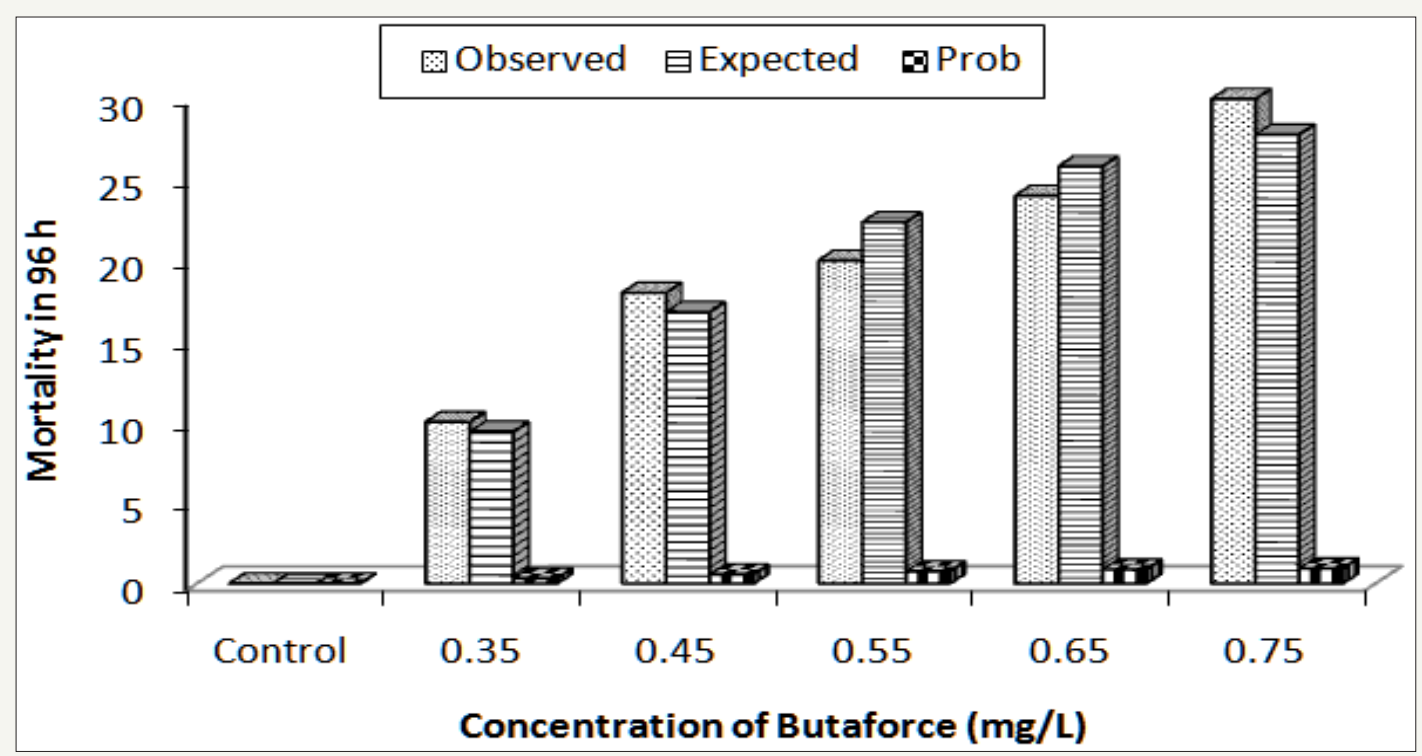

Figure 1: Response curve of Bufo regularis tadpole after 96h acute exposure to Butaforce.

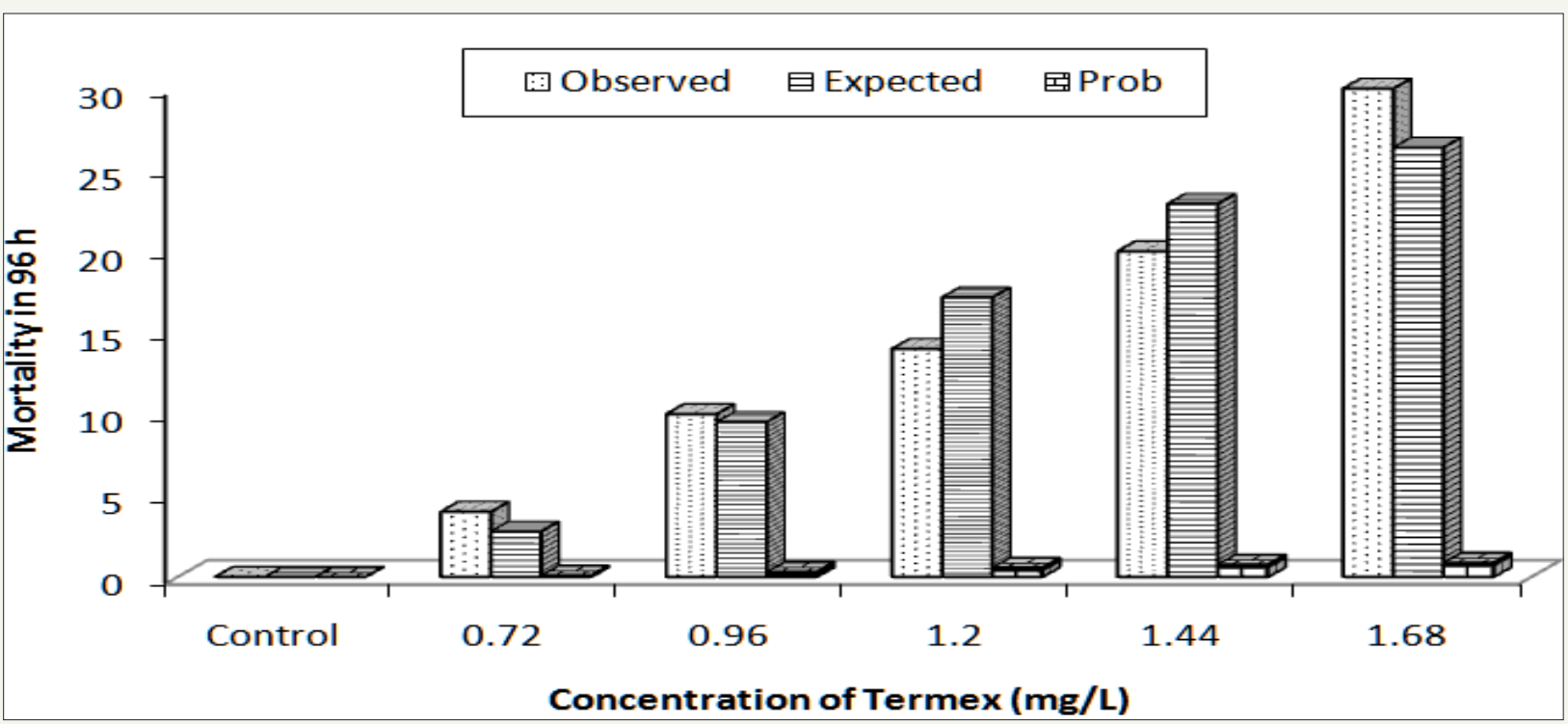

Figure 2: Response curve of Bufo regularis tadpole after $96 \mathrm{~h}$ acute exposure to Termex.

Table 1: Cumulative mortality of Bufo regularis exposed to various concentrations of butaforce and Termex.

\begin{tabular}{|c|c|c|c|c|c|c|c|c|}
\hline \multirow[b]{2}{*}{ Pesticide } & \multirow[b]{2}{*}{ Concentration (mg/L) } & \multirow[b]{2}{*}{ Number exposed } & \multicolumn{4}{|c|}{ Cumulative Mortality } & \multirow[b]{2}{*}{ Mortality (\%) } & \multirow[b]{2}{*}{ Survival (\%) } \\
\hline & & & 24-h & 48-h & 72-h & 96-h & & \\
\hline \multirow{6}{*}{ Butaforce } & Control & 30 & 0 & 0 & 0 & 0 & 0 & 100 \\
\hline & 0.35 & 30 & 2 & 5 & 7 & 10 & 33 & 67 \\
\hline & 0.45 & 30 & 2 & 7 & 13 & 18 & 60 & 40 \\
\hline & 0.55 & 30 & 3 & 7 & 13 & 20 & 67 & 33 \\
\hline & 0.65 & 30 & 4 & 10 & 18 & 24 & 80 & 20 \\
\hline & 0.75 & 30 & 6 & 14 & 24 & 30 & 100 & 10 \\
\hline
\end{tabular}




\begin{tabular}{|c|c|c|c|c|c|c|c|c|}
\hline \multirow{4}{*}{ Termex } & Control & 30 & 0 & 0 & 0 & 0 & 0 & 100 \\
\cline { 2 - 9 } & 0.7 & 30 & 0 & 1 & 2 & 4 & 14 & 86 \\
\cline { 2 - 9 } & 0.96 & 30 & 1 & 3 & 6 & 10 & 34 & 66 \\
\cline { 2 - 9 } & 1.2 & 30 & 2 & 4 & 8 & 14 & 47 & 37 \\
\cline { 2 - 9 } & 1.44 & 30 & 3 & 8 & 13 & 20 & 100 & 0 \\
\hline
\end{tabular}

Table 2: Estimate of safe levels of Butaforce and Termex at $96 \mathrm{~h}$ exposure duration to Bufo regularis.

\begin{tabular}{|c|c|c|c|c|}
\hline Chemical & 96h LC50 (mg/L) & Method & $\mathbf{A F}$ & Safe Level (Mg/L) \\
\hline \multirow{6}{*}{ Butaforce } & \multirow{6}{*}{0.42} & Hart et al. [12] & - & $1.42 \times 10^{-2}$ \\
\hline & & Sprague [13] & 0.1 & $4.2 \times 10^{-2}$ \\
\hline & & CWQC [14] & 0.01 & $4.2 \times 10^{-3}$ \\
\hline & & NAS/NAE [15] & $0.1-0.00001$ & $4.2 \times 10^{-2}-4.2 \times 10^{-6}$ \\
\hline & & CCREM [16] & 0.05 & $2.1 \times 10^{-2}$ \\
\hline & & IJC [17] & $5 \% \mathrm{LC}_{50}$ & $2.1 \times 10^{-2}$ \\
\hline \multirow{6}{*}{ Termex } & \multirow{6}{*}{1.13} & Hart et al. [12] & - & $3.30 \times 10^{-2}$ \\
\hline & & Sprague [123] & 0.1 & $1.13 \times 10^{-1}$ \\
\hline & & CWQC [14] & 0.01 & $1.13 \times 10^{-2}$ \\
\hline & & NAS/NAE [15] & $0.1-0.00001$ & $1.13 \times 10^{-1}-1.13 \times 10^{-5}$ \\
\hline & & CCREM [16] & 0.05 & $5.65 \times 10^{-2}$ \\
\hline & & IJC [17] & $5 \% \mathrm{LC}_{50}$ & $5.65 \times 10^{-2}$ \\
\hline
\end{tabular}

Studies on acute toxicity in Bufo regularis tadpoles showed variations in lethal concentration (LC10-90) values which were dependent on the type of the pesticides, concentrations and duration of exposure (Table $3 \& 4$ ). The toxicity of chemicals to organisms has been reported to be dependent on concentration, $\mathrm{pH}$, temperature, developmental stages, nature of toxicants and periods of exposures [26]. The significance differences in LC(1090), NOEC and LOEC obtained at different times of exposures of the pesticides are in agreement with those reported in fishes exposed to other pesticides $[23,26]$.The maximum allowable concentration (MAC) of butaforce was $4.2 \mathrm{mg} / \mathrm{L}$ while the value was $11.30 \mathrm{mg} / \mathrm{L}$ for termex in B. regularis tadpole thus indicating that butaforce is more toxic than termex. The comparative investigation of the $96 \mathrm{~h}$ $\mathrm{LC}_{50}$ of other pesticides in other anurans indicate that butaforce and termex are very toxic to the amphibians (Table 5). The results of statistical end points of toxicity of butaforce and termex showed variations of NOEC, $\mathrm{LOEC}$ and $\mathrm{LC}_{50}$ with respect to concentrations and duration of exposures (Figure $3 \& 4$ ). The variations in these end points were minimal in tadpoles exposed to termex thus indicating that the extent of lethality was dependent on the type of pesticide [27-30].

Table 3: Lethal concentration ( $\left.\mathrm{LC}_{10-90}\right)$ of butaforce depending on exposure time (24-96h) for Bufo regularis tadpole.

\begin{tabular}{|c|c|c|c|c|}
\hline \multirow{2}{*}{ Point } & \multicolumn{4}{|c|}{ Concentrations (mg/L) At Various Exposure Times (95\% Confidence Intervals) } \\
\hline & $24 \mathrm{~h}$ & $48 \mathrm{~h}$ & $72 \mathrm{~h}$ & $96 h$ \\
\hline \multirow{2}{*}{$\mathrm{LC}_{10}$} & 0.48 & 0.28 & 0.26 & 0.26 \\
\hline & $(0.22-0.58)^{\mathrm{a}}$ & $(0.03-0.39)^{\mathrm{b}}$ & $(0.15-0.33)^{\mathrm{b}}$ & $(0.17-0.31)^{\mathrm{b}}$ \\
\hline \multirow{2}{*}{$\mathrm{LC}_{20}$} & 0.67 & 0.42 & 0.33 & 0.3 \\
\hline & $(0.55-\mathrm{I} .31)^{\mathrm{a}}$ & $(0.16-0.52)^{a}$ & $(0.22-0.40)^{\mathrm{a}}$ & $(0.23-0.35)^{b}$ \\
\hline \multirow{2}{*}{$\mathrm{LC}_{30}$} & 0.85 & 0.56 & 0.4 & 0.35 \\
\hline & $(0.68-3.64)^{a}$ & $(0.43-0.79)^{a}$ & $(0.30-0.46)^{b}$ & $(0.27-0.39)^{\mathrm{b}}$ \\
\hline \multirow{2}{*}{$\mathrm{LC}_{40}$} & 1.04 & 0.72 & 0.46 & 0.38 \\
\hline & $(0.77-1.10)^{\mathrm{a}}$ & $(0.59-1.88)^{a}$ & $(0.38-0.52)^{b}$ & $(0.32-0.43)^{\mathrm{b}}$ \\
\hline \multirow{2}{*}{$\mathrm{LC}_{50}$} & 1.26 & 0.91 & 0.53 & 0.42 \\
\hline & $(0.87-21.61)^{a}$ & $(0.70-4.80)^{a}$ & $(0.47-0.61)^{\mathrm{b}}$ & $(0.37-0.47)^{\mathrm{b}}$ \\
\hline \multirow{2}{*}{$\mathrm{LC}_{60}$} & 1.53 & 1.15 & 0.61 & 0.47 \\
\hline & $(0.97-51.52)^{\mathrm{a}}$ & $(0.81-12.52)^{a}$ & $(0.55-0.74)^{b}$ & $(0.42-0.51)^{b}$ \\
\hline
\end{tabular}




\begin{tabular}{|c|c|c|c|c|}
\hline \multirow{2}{*}{ LC70 } & 1.87 & 1.48 & 0.71 & 0.52 \\
\cline { 2 - 5 } & $(1.09-130.78)^{\mathrm{a}}$ & $(0.94-35.22)^{\mathrm{a}}$ & $(0.62-0.94)^{\mathrm{b}}$ & $(0.48-0.58)^{\mathrm{b}}$ \\
\hline \multirow{2}{*}{ LC80 } & 2.38 & 1.98 & 0.85 & 0.59 \\
\cline { 2 - 5 } & $(1.26-389.66)^{\mathrm{a}}$ & $(1.11-118.63)^{\mathrm{a}}$ & $(0.71-1.27)^{\mathrm{b}}$ & $(0.54-0.68)^{\mathrm{b}}$ \\
\hline \multirow{2}{*}{ LC90 } & 3.32 & 2.96 & 1.08 & 0.7 \\
\cline { 2 - 5 } & $(1.52-1773.66)^{\mathrm{a}}$ & $(1.41-641.24)^{\mathrm{a}}$ & $(0.85-1.95)^{\mathrm{a}}$ & $(0.62-0.87)^{\mathrm{b}}$ \\
\hline
\end{tabular}

Table 4: Lethal concentrations $\left(\mathrm{LC}_{10-90}\right)$ of Termex depending on exposure time (24-96h) for Bufo regularis tadpoles.

\begin{tabular}{|c|c|c|c|c|}
\hline \multirow{2}{*}{ Point } & \multicolumn{4}{|c|}{ Concentrations (mg/L) At Various Exposure Times (95\% Confidence Intervals) } \\
\hline & $24 \mathrm{~h}$ & $48 \mathrm{~h}$ & $72 \mathrm{~h}$ & 96h \\
\hline \multirow{2}{*}{$\mathrm{LC}_{10}$} & 1.4 & 1.01 & 0.82 & 0.73 \\
\hline & $(1.09-2.00)^{\mathrm{a}}$ & $(0.69-1.17)^{\mathrm{a}}$ & $(0.61-0.95)^{\mathrm{a}}$ & $(0.16-0.94)^{\mathrm{a}}$ \\
\hline \multirow{2}{*}{$\mathrm{LC}_{20}$} & 1.79 & 1.29 & 0.01 & 0.85 \\
\hline & $(1.48-5.66)^{\mathrm{a}}$ & $(1.09-1.52)^{\mathrm{a}}$ & $(0.83-1.12)^{\mathrm{a}}$ & $(0.29-1.05)^{\mathrm{a}}$ \\
\hline \multirow{2}{*}{$\mathrm{LC}_{30}$} & 2.13 & 1.54 & 1.16 & 0.94 \\
\hline & $(1.66-13.22)^{\mathrm{a}}$ & $(1.34-2.08)^{\mathrm{a}}$ & $(1.02-1.29)^{\mathrm{a}}$ & $(0.45-1.16)^{b}$ \\
\hline \multirow{2}{*}{$\mathrm{LC}_{40}$} & 2.48 & 1.8 & 1.32 & 1.04 \\
\hline & $(1.84-27.6661)^{\mathrm{a}}$ & $(1.52-2.84)^{\mathrm{a}}$ & $(1.19-1.50)^{\mathrm{a}}$ & $(0.62-1.29)^{a}$ \\
\hline \multirow{2}{*}{$\mathrm{LC}_{50}$} & 2.85 & 2.07 & 1.48 & 1.13 \\
\hline & $(2.00-55.18)^{a}$ & $(1.69-3.86)^{a}$ & $(1.33-1.776)^{a}$ & $(0.80-1.50)^{\mathrm{a}}$ \\
\hline \multirow{2}{*}{$\mathrm{LC}_{60}$} & 3.28 & 2.4 & 1.66 & 1.23 \\
\hline & $(2.00-55.18)^{\mathrm{a}}$ & $(1.87-5.28)^{a}$ & $(1.47-2.09)^{\mathrm{a}}$ & $(0,97-1.88)^{\mathrm{a}}$ \\
\hline \multirow{2}{*}{$\mathrm{LC}_{70}$} & 3.53 & 2.79 & 1.89 & 1.35 \\
\hline & $(2.27-156.66)^{a}$ & $(2.07-7.39)^{a}$ & $(1.62-2.52)^{\mathrm{a}}$ & $(1.10-2.56)^{\mathrm{a}}$ \\
\hline \multirow{2}{*}{$\mathrm{LC}_{80}$} & 4.54 & 3.34 & 2.18 & 1.5 \\
\hline & $(2.62-555.60)^{a}$ & $(2.34-11.00)^{a}$ & $(1.82-3.21)^{a}$ & $(1.22-3.84)^{\mathrm{b}}$ \\
\hline \multirow{2}{*}{$\mathrm{LC}_{90}$} & 5.79 & 4.29 & 2.67 & 1.74 \\
\hline & $(3.01-1862.71)^{\mathrm{a}}$ & $(2.76-19.11)^{\mathrm{a}}$ & $(2.11-4.50)^{\mathrm{a}}$ & $(1.37-6.92)^{b}$ \\
\hline
\end{tabular}

Table 5: Acute toxicity studies of some pesticides in tadpoles.

\begin{tabular}{|c|c|c|c|}
\hline Pesticide & Assay & Result & References \\
\hline Glyphosate & $96 \mathrm{~h} \mathrm{LC}_{50}$ & $5.38 \mathrm{mg} / \mathrm{L}$ in P. albonotatus tadpole & Simioni et al. [21] \\
\hline Glifosan & $96 \mathrm{~h} \mathrm{LC}_{50}$ & $\begin{array}{l}20.81 \mathrm{mg} / \mathrm{L} \text { in } \text { O. septentrionalis } \\
\text { tadpole }\end{array}$ & Reyes et al. [24] \\
\hline Permethrin & $96 \mathrm{~h} \mathrm{LC}_{50}$ & $\begin{array}{l}2.50 \mu \mathrm{g} / \mathrm{L} \text { in Rana temporaria } \\
\text { tadpole }\end{array}$ & Johansson et al. [29] \\
\hline Esfenvalerate & $96 \mathrm{~h} \mathrm{LC}_{50}$ & 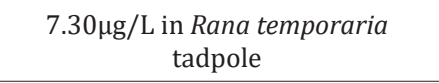 & Johansson et al. [29] \\
\hline Herbicide vision ${ }^{\circledR}$ & $96 \mathrm{~h} \mathrm{LC}_{50}$ & $11.50 \mathrm{mg} / \mathrm{L}$ in Rana pipiens tadpole & Wojtaszet and Staznik [30] \\
\hline Endosulfan & $96 \mathrm{~h} \mathrm{LC}_{50}$ & 0.074mg/L Rana dalmtina tadpole & Manuela et al. [6] \\
\hline Spent engine oil & $96 \mathrm{~h} \mathrm{LC}_{50}$ & $\begin{array}{l}2915 \mathrm{mg} / \mathrm{L} \text { in Amietophoryous } \\
\text { regularis tadpole }\end{array}$ & Amaeze et al. (2014) \\
\hline Unused engine oil & $96 \mathrm{~h} \mathrm{LC}_{50}$ & $\begin{array}{l}7353 \mathrm{mg} / \mathrm{L} \text { in Amietophoryous } \\
\text { regularis tadpole. }\end{array}$ & Amaeze et al. (2014) \\
\hline Endosulfan & $96 \mathrm{~h} \mathrm{LC}_{50}$ & $0.730 \mathrm{mg} / \mathrm{L}$ adult $B$. regularis & Ezemonye and Tango [20] \\
\hline Diazinon & $96 \mathrm{~h} \mathrm{LC}_{50}$ & $0.438 \mathrm{mg} / \mathrm{L}$ adult $B$. regularis & Ezemonye and Tango [20] \\
\hline Butaforce & $96 \mathrm{~h} \mathrm{LC}_{50}$ & $0.42 \mathrm{mg} / \mathrm{L}$ in Bufo regularis tadpole & This study \\
\hline Termex & $96 \mathrm{~h} \mathrm{LC}_{50}$ & $1.13 \mathrm{mg} / \mathrm{L}$ in Bufo regularis tadpole. & This study \\
\hline Dimethoate & $96 \mathrm{~h} \mathrm{LC}_{50}$ & $37.37 \mathrm{ppm}$ in Hyla arborea larvae & Ferah and Ugur (2005) \\
\hline
\end{tabular}




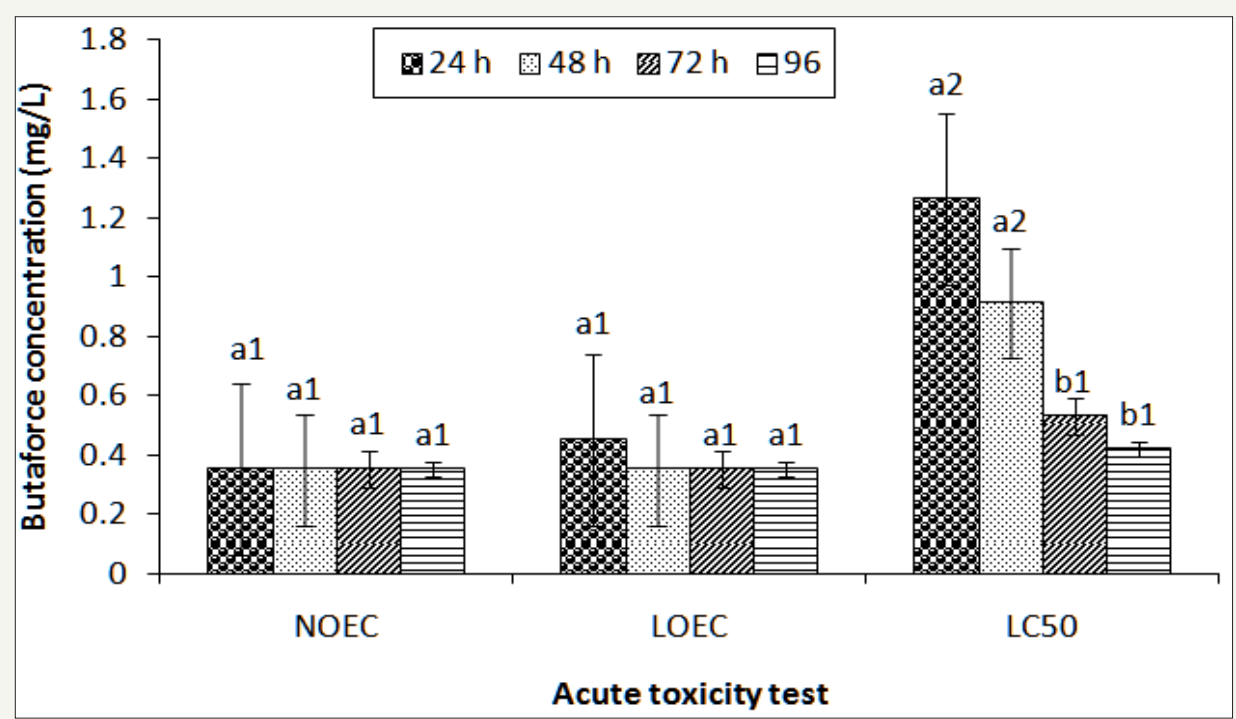

Figure 3: Acute toxicity testing statistical endpoints in Bufo regularis tadpole exposed to butaforce at different durations (24h, 48h, $72 \mathrm{~h}$ and $96 \mathrm{~h})$.

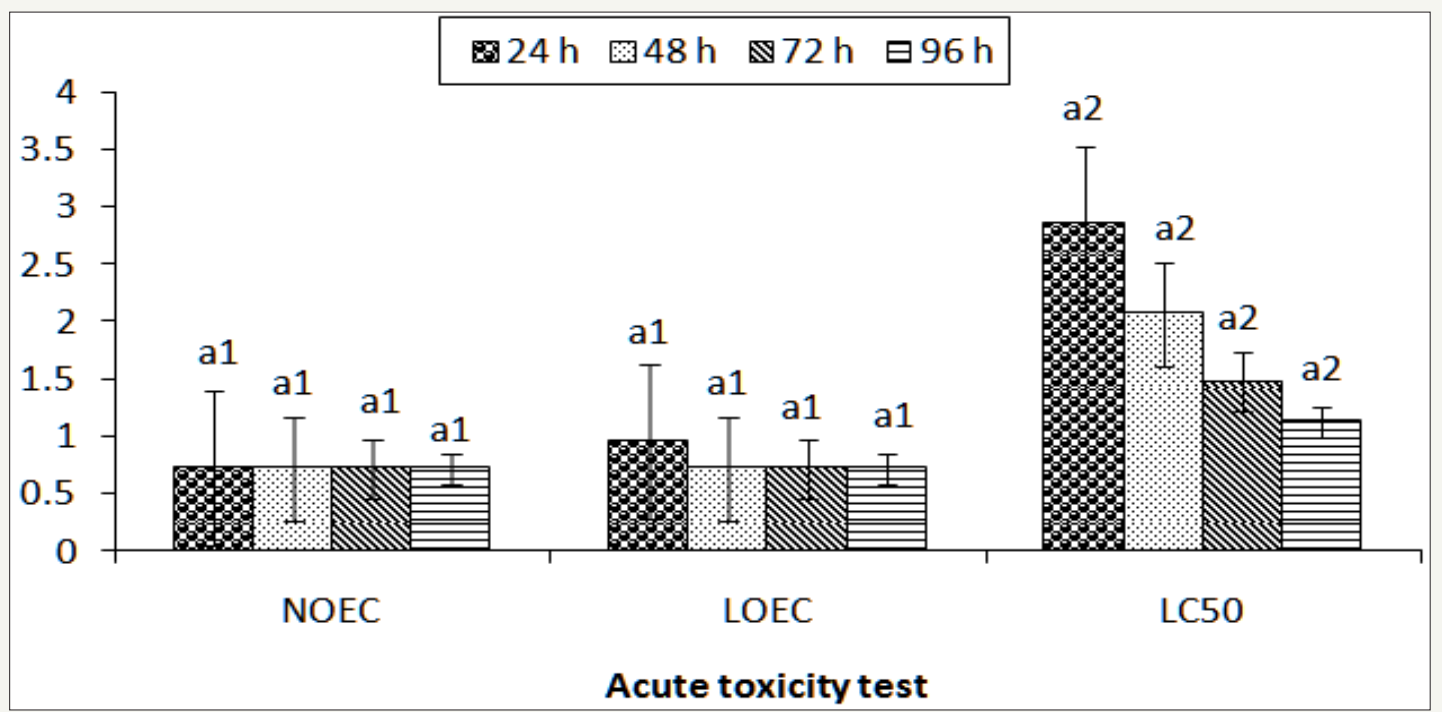

Figure 4: Acute toxicity testing statistical endpoints in Bufo regularis tadpole exposed to termex at different durations (24h, $48 \mathrm{~h}, 72 \mathrm{~h}$ and $96 \mathrm{~h})$.

\section{Conclusion}

In conclusion, both butaforce and termex pesticides are lethal to $B$. regularis tadpole and mortality is dependent on concentration and exposure duration. The two pesticides (butaforce and termex) should be applied with caution to avoid eco-toxicological effect on non target organisms such as tadpoles in the aquatic ecosystems.

\section{Acknowledgement}

The authors are grateful to Department of Zoology and Environmental Biology, University of Nigeria Nsukka for the materials and the laboratory equipment used during the research.

\section{References}

1. Dogan D, Can C (2011) Hematological, biochemical, and behavioral responses of Oncorhynchus mykiss to dimethoate. Fish Physiol Biochem 37(4): 951-958.
2. Smalling KL, Reeves R, Muths E, Vandever M, Battaglin WA, et al. (2015) Pesticide concentrations in frog tissue and wetland habitats in landscape dominated by agriculture. Sci Total Environ 502: 80-90.

3. William Q (2015) Pesticides and amphibian decline. Bio Integrated and Resource Centre Berkeley, US.

4. Ayansina ADV, Mohammad RG (2014) An evaluation of the effect of four herbicides on some aquatic organisms. International Journal of Biological and Chemical Sciences 8(1): 304-313.

5. Leonard RA (1989) Herbicides in surface waters. In Environmental Chemistry of herbicides 1: 45- 83.

6. Manuela L, Ilaria B, Anthonia C (2013) Endosulfan effects on Rana Dalmatina tadpoles: Quantitative developmental behavioural analysis. Arch Environ Contam Toxicol 64(2): 253-262.

7. htt://www.jcuedu.au

8. Ward GS, Parish PR (1982) Manual of Record of Methods. In: Ward GS, Parish PR (Eds.), Aquatic Environmental Research Part 6 . Toxicol Test 23 FAO Fish Technical Paper 185, USA. 
9. Reish DJ, Oshida RS (1987) Manual of Methods in Aquatic Environment Research. In: Reish DJ, Oshida RS (Eds.), Manual of Methods in Aquatic Environment Research. Short-term Static Bioassay, 62 FAO Fish Technical Paper 247, USA.

10. APHA, AWWA, WPCE (2005) Standard Methods for the Examination of Water and Waste Water. In: Standard Methods for the Examination of Water and Waste Water. (21 $1^{\text {st }} 401$ edn), American Public Health Association, Washington, US.

11. Hedayati A, Safahieh A, Savari A, Maramazi JG (2010) Detection of mercury chloride acute toxicity in yellowfin Sea Bream (Acanthopagrus latus). World Journal of Fish and Marine Science 2: 86-92.

12. Hart WB, Weston RF, Dermann JG (1948) An apparatus for Oxygenating test solution which fish are used as test animals for evaluating toxicity. Journal of the American Fisheries Society 75(1): 228-236.

13. Sprague JB (1971) Measurement of Pollutant Toxicity to Fish I. Bioassay methods for acute toxicity. Water Research 3(11): 793-821.

14. CWQC (Committee on Water Quality Criteria). (1972): A Report of the Committee on Water Quality Research Series, EPA-R3-73-003. Cincinnati, OH: US Environmental Protection Agency Report, CWQC.

15. NAS/NAE (National Academy of Sciences/National Academy of Engineering). (1973): Water Quality Criteria, EPA-R3-033. Washington DC: US Government Printing Office.

16. CCREM (Canadian Council of Resources and Environmental Ministry) (1991): Canadian Water Quality Guidelines; Canadian Council of Resources and Environmental Ministry. Ottawa Inland Waters Directorate. Environment Canada.

17. (1977) IJC (International Joint Commission). New and Revised Great lakes water Quality Objectives Ottawa: IJS, Canada.

18. Allran JW, Karasov WH (2001) Effects of atrazine on embryos, larvae and adults of anuran amphibians. Environmental Toxicology and Chemistry 20(4): 769-775.

19. Hayes T, Haston TM, Hoang A, Haefelle C, Vonk A (2003) Atrazine induced hermaphroditism at $0.1 \mathrm{pp}$ in American Leopard Frogs (Rana pipiens): Laboratory and field evidence. Environment Health Perspective 111: $568-575$

20. Ezemonye L, Tongo I (2010) Acute toxic effects of endosulfan and diazinon pesticides on adult Amphibians (Bufo regularis). Journal of Environmental Chemistry and Ecotoxicology 2(5): 73-78.
21. Simioni DFN, Silva DA, Mott T (2013) Toxicity of Glyphosate on Physalaemus albonotatus. Ecotoxicology and Environmental Contamination 8(1): 55-58.

22. Mount DI, Stephan CI (1967) A method for establishing acceptable toxicant limits for fish-malathion and the butoxyethanol Ester of 2, 4-D. Transactions of the American Fisheries Society 96(2): N185-193.

23. Ani LC, Nwamba HO, Ejilibe CO, Nwani CD (2017) Acute toxicity of glyphosate-based herbicide glycot on juvenile African cat fish Clarias gariepinus (Burchell 1822). Journal of Fisheries and Livestock Production 5(3): 1-4.

24. Reyes MEA, Hondal OC, Hernandez JT, Aleman MAT (2003) Toxicidal aguda del herbicida quimico Glifosan en larvas de larana cubana: Osteopilus septentrinalis. Revista de Toxicologia en hirea, pp. 34-45.

25. Pandey S, Kumar R, Sharma S, Nagpure NS, Srivastava SK (2005) Acute toxicity bioassays of mercuric chloride and malathion on air breathing fish Channa punctatus (Bloch). Ecotoxicology and Environmental Safety 61(1): $114-120$

26. Hedayati A, Vajargah MF, Yalsuyi AM, Abarghoei S, Hajiahmadyan M, et al. (2014) Acute toxicity test of pesticide abamectin on common carp (Cyprinus carpio). Journal of Coastal Life Medicine 2(11): 841-844.

27. Vajargah MF, Hedayati A, Yalsuyi AM, Abarghoei S, Gerami MH, et al. (2014) Acute toxicity of butachlor to Caspian Kutum (Rutilus frisii kutum Kamensky, 1991). Journal of Environmental Treatment Techniques 2(4): 155-157.

28. Finney DJ (1971) Probit Analysis. In: Finney DJ (Ed.), Probit Analysis. Cambridge University Press, UK.

29. Johansson M, Piha H, Kylin H, Merila J (2006) Toxicity of six pesticides to common frog Rana temporaria tadpoles. Environ Toxicol Chem 25(12): 3164-3170.

30. Wojtaszek BF, Staznik B, Chartrand DI, Stephenson GR, Thompson DG (2004) Effect of vision ${ }^{\circledR}$ herbicide on mortality, avoidance response, and growth of amphibian larvae in two forest wetlands. Environ Toxicol Chem 23(4): 832-842.

\section{Your subsequent submission with Crimson Publishers will attain the below benefits}

- High-level peer review and editorial services

- Freely accessible online immediately upon publication

- Authors retain the copyright to their work

- Licensing it under a Creative Commons license

- Visibility through different online platforms

- Global attainment for your research

- Article availability in different formats (Pdf, E-pub, Full Text)

- Endless customer service

- Reasonable Membership services

- Reprints availability upon request

- One step article tracking system 